\title{
A "máquina do mundo" e a filosofia do absurdo: Drummond, leitor de Albert Camus
}

\author{
Cleber Ranieri Ribas de Almeida*
}

\section{Resumo}

O artigo tenta provar que o poema A Máquina do Mundo, de Carlos Drummond de Andrade, foi parcialmente escrito a partir da reutilização de diversas metáforas, imagens e conceitos extraídos do livro O Mito de Sísifo, de Albert Camus. No intuito de demonstrar essa hipótese destacamos alguns excertos do livro de Camus e os cotejamos com metáforas e imagens análogas encontradas em A Máquina do Mundo. A conclusão a que chegamos é a de que Drummond reelaborou metaforicamente a filosofia do sentimento do absurdo em várias passagens do poema. Tal reelaboração intertextual, poética e metafórica se dera como uma resposta negativa e antitética à visão epifânica e cristã da criação universal descrita poeticamente por Jorge de Lima no Livro de Sonetos.

Palavras-chave: A Máquina do Mundo. Carlos Drummond de Andrade. Albert Camus.

Professor Associado da Universidade Federal do Piauí (UFPI), Doutor em Filosofia pela Universidade de São Paulo (USP), http://orcid.org/0000-0002-9617-5344. 


\title{
The "machine of the world" and the philosophy of the absurd: Drummond, reader of Albert Camus
}

\begin{abstract}
The article aims to prove that the poem "A Máquina do Mundo," by Carlos Drummond de Andrade, was partially written by reutilizing of a number of metaphors, images, and concepts extracted from Albert Camus's Le Mythe de Sisyphe (1942). To the end of demonstrating this hypothesis, we highlight some excerpts from Camus's book, paralleling them with analogous metaphors and images we find in "A Máquina do Mundo." The conclusion we reach is that Drummond remade, metaphorically, the philosophy of the feeling of the absurd in various passages of his poem. Drummond elaborated this remaking of Camus's images, philosophy, and concepts as a negative and antithetical answer to the epiphanic and Christian vision of the universal creation poetically described by Jorge de Lima in the Livro de Sonetos (1949).
\end{abstract}

Keywords: The Machine of the World. Carlos Drummond de Andrade. Albert Camus.

Recebido em: 17/06/2021 // Aceito em: 27/11/2021. 


\section{Introdução}

O poema A Máquina do Mundo, de Carlos Drummond de Andrade, foi considerado pela crítica acadêmica especializada o maior poema da história da literatura brasileira (Dias, 2000). Enigmático e misterioso, o texto se apresentou aos seus leitores, desde a primeira publicação, como um arcano que intimidava e inibia quem quer que tentasse desvelar o sentido último de seus tercetos. Apesar dessa intimidação inicial, ao longo dos anos a fortuna crítica drummondiana foi aos poucos desvelando os expedientes intertextuais usados por Drummond na hora de pensar e realizar o poema. Os primeiros intérpretes, como Silviano Santiago (1966), identificaram a projeção da imagem epifânica da máquina do mundo como um intertexto com o Canto Décimo d'Os Lusíadas de Luís de Camões (1997). Outros, como Eduardo Dall'Alba (1996), perceberam que Drummond redesenhou o cenário d'A Divina Comédia, de Dante Alighieri, no qual o poeta-narrador, caminhando por um cammin ou estrada, depara-se repentinamente com uma visão luminar e reveladora.

Além dessas interpretações canônicas que identificaram intertextos com as alegorias de Dante e Camões, surgiram posteriormente estudos que se propunham enfatizar o diálogo íntimo do poeta mineiro com questões e conceitos originários do existencialismo sartreano, temas como a náusea, a revolta, a angústia, o humanismo, o nada (PRADO JR., 2014; PERIUS, 2015; TAKAO, 2018). A filosofia existencialista seria, para esses intérpretes, o stimmung que perpassaria toda a poesia drummondiana, fosse a poesia de envergadura social, como testemunhamos em A Rosa do Povo (1945), fosse a poesia metafísica, como vemos em Claro Enigma (1951). 
Seguindo esse viés hermenêutico "existencialista", ${ }^{1}$ neste breve estudo investigaremos em que medida o poema A Máquina do Mundo (2002, p. 301-304) foi pensado e concebido pelo poeta mineiro como um diálogo poético com o livro Le Mythe de Sisyphe (1942), ${ }^{2}$ de Albert Camus. Como veremos, muitos foram os artifícios intertextuais utilizados por Drummond no que diz respeito à reelaboração poética de imagens, metáforas e conceitos oriundos da filosofia do absurdo de Camus. O pensador franco-argelino fora para o poeta itabirano não só um herói filosófico, mas, sobretudo, uma personae ${ }^{3}$ cuja voz ressoou poeticamente na fala do poeta-narrador. E essa personae ou máscara através da qual a voz e o pensamento do filósofo ressoaram não deve ser entendida como mera evocação, mas como uma disposição dramática.

Daí que poderíamos interpretar várias passagens de $\mathrm{A}$ Máquina do Mundo como evidências dessa reencarnação dramática na qual Drummond fez-se porta-voz poético da filosofia do homem absurdo. Detectamos onze (11) evidências dessa relação - intertextual, dramática e filosófica - entre o poeta mineiro e seu alter ego filosófico, quais sejam: (1) a disposição dramática do poeta-narrador em relação ao filósofo do absurdo, Camus, quando Drummond assinala que a epifania

\footnotetext{
1 Em verdade, embora haja diversos estudos acerca da influência da filosofia existencialista sartreana sobre a poesia de Drummond, o mesmo não ocorre em relação à filosofia do absurdo de Camus. Há um único estudo (DE CASTRO CÂNDIDO; RIBEIRO DA COSTA; NOGUEIRA; 2017) que investiga "aproximações" entre imagens desenhadas por Drummond em Sentimento do Mundo e "pensamentos desenvolvidos em O Mito de Sísifo". Tais aproximações, entretanto, são anacrônicas porque Sentimento do Mundo foi publicado em 1940 enquanto O Mito de Sísifo data de 1942. Drummond não poderia ter "aproximações" com uma obra antes que ela fosse publicada. Usamos aspas em "existencialista" porque Camus negava sua filiação a essa corrente filosófica. "Não sou e nunca fui existencialista", disse o argelino a Yvonne Jean numa entrevista publicada no Correio da Manhã em dia 24 de julho de 1949.

2 No que diz respeito às diversas citações do livro $\mathbf{O}$ Mito de Sísifo, neste estudo vali-me da edição em francês da Gallimard (2010), bem como das traduções de Ari Roitman e Paulina Watch (2019a), Urbano Tavares Rodrigues (2020) e, sobretudo, da tradução de Mauro Gama (1989).

3 Emprego personae aqui no sentido etimológico originário de alguma coisa através da qual os sons se fazem ouvir, tal como eram utilizadas as máscaras de Tália e Melpômene no teatro grego. Os atores usavam estas máscaras (personae) porque elas ressoavam ou davam voz a pensamentos e ações dos personagens, daí o termo per-sonare, "soar através de" (FAITANIN, 2006).
} 
da máquina o dispôs de tal modo que era "como se outro ser/ [...] passasse a comandar sua vontade"; (2) a reutilização da imagem do caminho conforme esta aparece de modo similar em O Mito de Sísifo e em A Máquina do Mundo; (3) a reiteração, por Drummond, da metáfora camusiana da "luz sem cintilação" (dans sa lumière sans rayonnement); (4) a reutilização, no texto drummondiano, da metáfora do "mundo 'espesso" (épais) segundo a define Camus; (5) o reemprego, pelo poeta de Itabira, da metáfora do deserto como representação pictórica do sentimento do absurdo; (6) a reelaboração do tema da "realidade transcendente" cujo rosto é o próprio mistério ou abismo; (7) a reaparição do tema da esperança como "virtude" antitética ao sentimento do absurdo; (8) a repetição do tema da recusa à explicação total da vida (ou recusa ao salto para a eternidade); (9) a reiteração da experiência da lassidão como interrupção da vida maquinal e cotidiana de homens que passam, abruptamente, a se perguntar sobre o sentido da vida (Camus define a lassidão como o início da autoconsciência do homem absurdo); (10) o uso, por Drummond, da metáfora da "neutra face" como sinônimo de indiferença espiritual do homem absurdo diante das tentações da fé; (11) a reelaboração do tema da noite como um símbolo do pensamento absurdo.

Além dessas evidências intertextuais, é consabido pelos biógrafos que, entre os dias 15 de julho e 23 de agosto de 1949, Camus esteve no Brasil em turnê oficial, a convite do governo da França, para proferir conferências em várias cidades do território nacional, dentre as quais, Rio de Janeiro, São Paulo, Recife, Salvador e Porto Alegre (GESKE, 2020). O próprio pensador argelino registrou suas impressões sobre os encontros com Aníbal Machado, Oswald de Andrade, Manuel 
Bandeira, Augusto Frederico Schmidt, Érico Veríssimo e Murilo Mendes (CAMUS, 2017). Igualmente, vários desses escritores brasileiros, além de alguns jornalistas, relataram suas impressões sobre a personalidade do jovem e renomado novelista de A Peste. De todo modo, a despeito da longa estada do autor no Rio de Janeiro, os biógrafos jamais detectaram qualquer registro ou notícia sobre um possível encontro entre Camus e Drummond, certamente porque tal encontro jamais ocorreu. ${ }^{4}$ Não obstante, é bem conhecido o impacto cultural, literário e jornalístico provocado pela presença do pensador argelino entre os mais ilustres intelectuais brasileiros da época. É provável que Drummond, amigo de Murilo Mendes, ${ }^{5}$ estivesse a par das conversas de bastidores e dos eventos sociais protagonizados por Camus, como fora o caso da conferência intitulada Les Temps des Meurtriers, proferida no auditório do Ministério da Educação, no Rio de Janeiro, no dia 20 de julho de 1949, além da palestra Roman et Révolte, proferida na Associação Brasileira de Imprensa (ABI), em 23 de agosto de 1949. Essa presença física e espiritual de Camus, decerto, não apenas aproximou mais o poeta mineiro da obra filosófica do pied noir, como inspirou Drummond a valer-se das metáforas da filosofia do absurdo como material de criação poética. Basta nos lembrarmos que o poema A Máquina do Mundo foi redigido, provavelmente, entre

\footnotetext{
4 O único indício de que Drummond e Camus tenham se encontrado, até onde podemos especular, está no relato de Manuel Bandeira, "Recordações de Camus", escrito por ocasião do falecimento do pensador argelino num fatídico acidente de carro, no dia 4 de janeiro de 1960. Bandeira assinala que "Alguns amigos brasileiros do grande escritor, uns vinte, entre os quais Murilo Mendes, tiveram a boa idéia de lhe oferecer um almoço de despedida num restaurante português na Rua do Ouvidor, perto do cais [...]” (BANDEIRA, 1990, p. 693-694). Esse indício, contudo, é improvável porque Bandeira certamente faria menção ao nome de Drummond caso o poeta mineiro estivesse presente. O jornal Correio da Manhã, de 2 de agosto de 1949, aponta quem eram os convivas daquele dia. A maioria eram ministros, embaixadores e professores.

5 Numa crônica datada de 23 de agosto de 1949, publicada no Diário de Notícias e intitulada "Várias", Rubem Braga nos relata a visita de Camus à casa de Murilo Mendes num tom bastante descontraído: "E conheci na casa de Murilo Mendes o sr. Albert Camus, que parece ser boa praça, mas interrogado por duas jovens (uma bailarina e uma assistente social) sobre se era casado, respondeu "plusieurs fois", o que encerrou o assunto. Alguns cavalheiros brasileiros em volta suspiraram de inveja [...]".
} 
agosto e setembro de 1949, tendo em vista que fora publicado em primeira mão no jornal Correio da Manhã, no dia 2 de outubro de 1949.

O propósito deste breve estudo, portanto, é examinar em pormenor cada uma das onze evidências acima indicadas de modo a esclarecer uma possível relação intertextual, dramática e filosófica entre o poeta-narrador de A Máquina do Mundo e o pensador do absurdo de O Mito de Sísifo.

\section{A disposição dramática}

A disposição dramática (evidência 1) de Drummond, o poeta do "absurdo original e seus enigmas", pode ser depreendida dos versos nos quais o narrador relata ter sido tomado por "outro ser" quem, desde então, passou a comandar sua vontade e, assim, o dispôs a recusar a "coisa oferta" pela máquina. Essa situação hipotética é descrita nos seguintes tercetos:

[...] como defuntas crenças convocadas presto e fremente não se produzissem a de novo tingir a neutra face

que vou pelos caminhos demonstrando, e como se outro ser, não mais aquele habitante de mim há tantos anos,

passasse a comandar minha vontade que, já de si volúvel, se cerrava semelhante a essas flores reticentes

em si mesmas abertas e fechadas; como se um dom tardio já não fora apetecível, antes despiciendo,

baixei os olhos, incurioso, lasso, 
desdenhando colher a coisa oferta

que se abria gratuita a meu engenho.

(DRUMMOND, 2002, p. 303)

O poeta relata aí a confrontação entre o eu "habitante de mim há tantos anos" (referindo-se, certamente, ao Drummond itabirano, filho de família tradicional católica mineira) e o eu camusiano, homem sem fé, alheio àquelas "defuntas crenças" agora imprestáveis para "de novo tingir a neutra face" do poeta. Esse segundo eu seria, portanto, a personificação dramática do homem absurdo. Voluntariamente arrebatado por "outro ser", o poeta-narrador passa então a reconhecer em si a existência destes dois eus: um que compreende a recusa como um gesto corajoso de negação de toda "ciência sublime e formidável, mas hermética", e outro que, no intuito de se livrar do peso existencial do absurdo, cogita capitular ante as tentações da fé e saltar em direção ao "trampolim da eternidade" (CAMUS, 1989, p. 30). Nesse confronto interior, a decisão de recusar a "coisa oferta" pela máquina fora então tomada pelo eu absurdo, não pelo eu das "defuntas crenças". A aparição da máquina permitiu que o poeta se autodescobrisse, quer dizer, ele passou, desde então, a compreender quem ele é. Essa autocompreensão provocada pela epifania da máquina revelou-se assim, também, a epifania interior de um homem que se descobriu como um homem absurdo. A filosofia de Camus tornou-se para ele um espelho, ou melhor, um reflexo de sua própria face neutra. ${ }^{6}$ Nesse sentido, o caminho percorrido pelo poeta do absurdo fora, sobretudo, um caminho que o conduziu a um encontro consigo próprio. Como enfatizou Camus, seria o "caminho sem saída" do homem absurdo que precisa "perder-se para se reencontrar" (CAMUS, 1989, p. 59).

6 Segundo Camus: "O estranho que em determinados momentos vem ao nosso encontro num espelho, o irmão familiar e no entanto inquietante que reencontramos em nossas próprias fotografias, é ainda o absurdo [...]” (CAMUS, 1989, p. 15). 
Em face desse arrebatamento filosófico e espiritual pelo eu absurdo, ao longo do poema Drummond se autodescreve como desenganado, esquivo, temeroso, carpido, noturno, miserável, homem de pouca fé, sem esperança, desprovido de ânsia por conhecimento, reconhecido por sua "neutra face", cético em relação às "defuntas crenças" e, finalmente, um homem tão obscuro interiormente a ponto de difundir sua escuridão pelos montes. Além disso, o poeta vê a vida como uma repetição dos "mesmos sem roteiro tristes périplos", ou seja, entende que a trajetória biográfica de cada pessoa, ainda que peculiar, conduzirá, ao fim das contas, todas elas à morte. ${ }^{7}$ Afinal, a morte é, para o homem absurdo, não apenas o epicentro da vida, mas a prova cabal de que a vida não faz sentido, porque finita. ${ }^{8}$

Dada essa autodescrição, como poderíamos definir a disposição dramática de Drummond, o poeta-narrador de A Máquina do Mundo, em relação a Camus, o pensador do absurdo em O Mito de Sísifo? Ao se deparar com a máquina Drummond dispôs-se como um ator a representar um personagem com o qual se identificou filosófica e pessoalmente. Assim, pôs em prática o preceito camusiano segundo o qual o ofício do ator é a "arte da multiplicação herética das almas" (CAMUS, 1989, p. 60). Drummond, o ator, personificou os atributos filosóficos e espirituais do personagem por ele representado de tal modo que sua voz se tornou o eco da voz de Camus. Daí que o estilo da escrita poética drummondiana tenha se amalgamado às imagens e metáforas extraídas de O Mito de Sísifo como se ambas as

\footnotetext{
Alfredo Bosi (2003) interpreta esse verso como "expressão de um círculo vicioso, aparentemente sem saída", sem atentar que Drummond está a falar da morte como horizonte último da vida, isto é, está a reiterar um tópos da filosofia do absurdo.

8 Também o tema camusiano da vontade volúvel do eu é aí descrito por Drummond mediante o uso da metáfora das "flores reticentes" que se cerram "em si mesmas abertas e fechadas": abertas à recusa da "explicação total da vida", fechadas aos encantos da fé e da esperança; abertas ao sentimento do absurdo, fechadas àquelas "defuntas crenças". Numa passagem de $\mathbf{O}$ Mito de Sísifo, Camus descreve a volubilidade do eu absurdo comparando-o metaforicamente com a fluidez da água: "[...] se tento agarrar este eu de que me apodero, se tento defini-lo e sintetizá-lo, ele não é mais do que uma água que corre entre meus dedos [...]" (CAMUS, 1989, p. 18).
} 
vozes tivessem uma unidade de tom, ou, como definiu Camus, como se ambas as vozes fossem regidas pelo princípio da "monotonia" (CAMUS, 1989, p. 60). O rapsodo emprestou sua voz ao personagem para que o personagem falasse com a voz do rapsodo. Camus nos explica essa unidade de tom que caracteriza a arte do ator quando nos adverte que todo ator "transporta consigo" a vida dos personagens com os quais "se identifica":

Em que medida o ator se beneficia desses personagens, é difícil dizer. Mas o importante não está aí. Trata-se de saber, apenas, até que ponto ele se identifica com essas vidas insubstituíveis [que interpreta]. Acontece, realmente, que ele as transporta consigo, e que elas excedem sutilmente o tempo e o espaço em que nasceram: acompanham o ator, que já não se separa facilmente daquilo que ele foi. Ocorre que, para pegar o seu copo, ele redescobre o gesto de Hamlet levantando a taça. Não, não é tão grande a distância que o separa dos seres que ele faz viver. Ilustra, então, todos os meses, ou todos os dias, e abundantemente, essa verdade tão fecunda de que não há fronteira entre o que um homem quer e o que ele é. (CAMUS, 1989, p. 58)

$\mathrm{O}$ ator deve aprender a dominar os personagens que representa sem se deixar dominar por eles. E esse domínio será melhor exercido quanto mais personagens o ator interpretar ao longo de sua vida (CAMUS, 1989, p. 61). ${ }^{9}$ Embora não sejam homens absurdos, os atores têm em comum com os absurdistas o destino de reviver e experimentar a "glória perecível" e "efêmera" de outras vidas como se fossem suas (CAMUS, 1989, p. 58). Assim é que, em três horas de encenação o ator "experimenta e expressa todo um destino excepcional", de modo que a efemeridade do personagem em cena sintetiza a efemeridade da

9 Segundo Camus, "é no tempo que [o ator] aprende a dominá-los [os personagens]. Quanto mais vidas diferentes ele viveu, melhor se separa delas [...]" $(1989$, p. 61). 
vida tal como a vê o homem absurdo. Os atores e os absurdistas, afirma Camus, sabem que a vida é um sonho evanescente cuja conclusão está no fato de que "um dia tudo tem que morrer" (CAMUS, 1989, p. 59). ${ }^{10} \mathrm{Ou}$, como disse Drummond, todos teremos "os mesmos sem roteiro tristes périplos".

Ora, se o ator deve aprender a dominar os personagens que representa sem se deixar dominar por eles, essa disposição dramática camusiana pode ser compreendida como uma negação da disposição heteronômica conforme a vivenciou Fernando Pessoa. Como sabemos, Pessoa foi um poeta cujos heterônomos o dominaram completamente. Não por acaso, a palavra "heteronomia", usada para qualificar os outros eus pessoanos, designa "sujeição a uma lei exterior ou à vontade de outrem; ausência de autonomia [...]" (HETERONOMIA, 2009). E essa disposição heteronômica não deve ser confundida com a disposição dramática camusiana adotada por Drummond em A Máquina do Mundo. Carlos não encarnou uma personalidade estranha à sua própria pessoa, isto é, não deixou de ser ele mesmo, tampouco passou a ter outro nome, biografia e estilo de redação poética. Ele apenas personificou poeticamente o espírito absurdista da filosofia de Camus e deu a tal espírito uma versão pessoal.

Daí que o poeta tenha usado a locução conjuntiva que nos remete a uma situação hipotética: "e como se outro ser/ [...] passasse a comandar minha vontade [...]". A situação é imaginária, logo não efetiva, porque o poeta-narrador controla o personagem que compôs. Por isso pode representá-lo. Ao mesmo

\footnotetext{
10 Como assinalou Camus: “[um] ator dispõe de três horas para ser Iago ou Alceste, Fedra ou Gloucester. Nesse breve período, ele os faz nascer e morrer em cinquenta metros quadrados de tábuas. Nunca o absurdo foi tão bem ilustrado, nem por tanto tempo [...]" (1989, p. 61). À exceção da representação teatral, a experiência do absurdo, segundo Camus, não poder perdurar por duas horas. Por isso Drummond assinalou que sua experiência absurdista ocorreu num "relance" ("tudo se apresentou neste relance").
} 
tempo, ao personificar Camus, Drummond não deixou de ser ele mesmo, porque a voz do personagem permaneceu sendo a voz do ator. Camus nos fala deste "como se" e o define como uma das disposições espirituais do homem absurdo. Uma vez que esse homem tenha feito a escolha vital pela ação mundana em detrimento da contemplação do eterno, ele deve necessariamente "viver com o tempo e morrer com ele" (CAMUS, 1989, p. 63). A despeito dessa escolha pela vida ativa, ele sabe, assim como os conquistadores e colonizadores, que jamais poderá "restaurar os homens". Ainda assim, deve agir "como se" tal restauração fosse possível. Nessa lógica, agir "como se" significa "estar ao lado da luta" sem se frustrar com as derrotas que virão dessa jornada.

Os conquistadores sabem que a ação, em si, é inútil. Só existe uma ação útil: a que restaura o homem e a terra. Eu não vou nunca restaurar os homens. Mas é preciso fazer "como se" (comme si). Pois o caminho da luta me leva a redescobrir a carne. Mesmo humilhada, a carne é a minha única certeza. Só posso viver dela. A criatura é a minha pátria. Eis por que escolhi esse esforço absurdo e sem perspectiva. Eis por que estou do lado da luta. A época se presta a isso [...] (CAMUS, 1989, p. 63).

Ao empregar o "como se", ${ }^{11}$ nesses tercetos supracitados, Drummond está a nos dizer implicitamente: "sei que não sou Camus, mas vou pensar e agir como se fosse". De fato, se Camus estivesse diante da máquina do mundo e ela lhe oferecesse aquelas dádivas da ciência e da fé, o filósofo certamente as recusaria, "desdenhoso", "incurioso" e "lasso".

Finalmente, podemos dizer que essa disposição dramática de Drummond em relação à filosofia do absurdo tinha ainda outra razão de ser. O poeta utilizou as metáforas, imagens e

11 O uso reiterado da locução conjuntiva "como se" é, também, uma reelaboração do poema de W. H. Auden, As I Walked Out One Evening. 
conceitos da filosofia camusiana para se contrapor à visão cristã da criação universal conforme a descrevera poeticamente Jorge de Lima (1949) no Livro de Sonetos. Como já dissemos, A Máquina do Mundo fora publicada em primeira mão, e ainda em versão preliminar, no dia 2 de outubro de 1949, no jornal Correio da Manhã. Essa mesma versão preliminar fora novamente publicada, em novembro de 1949, na revista católica A Ordem. A decisão de dar ensejo a uma segunda publicação do poema numa revista de circulação católica tinha por propósito, certamente, responder ao Livro de Sonetos. Jorge de Lima era autor e leitor assíduo dessa revista. Ainda que essa hipótese não constitua o escopo deste artigo, ela nos é relevante porque explica, por outro ângulo, os motivos que levaram Drummond a utilizar amplamente o vocabulário da filosofia do absurdo de Albert Camus. O propósito do poeta itabirano era negar a visão epifânica, cristã e mística da criação universal segundo o relato poético de Jorge de Lima.

\section{Drummond e as imagens camusianas}

Como dissemos (evidência 2), Drummond valeu-se da imagem do caminho, não apenas porque ela está tanto n'A Divina Comédia de Dante quanto no poema de W. H. Auden (2007, p. 134-135), ${ }^{12}$ mas também porque tal imagem é a linha condutora de toda argumentação de Camus n’O Mito de Sísifo. ${ }^{13}$ Assim,

\footnotetext{
12 Refiro-me ao poema $A s I$ Walked Out One Evening, do qual Drummond extraiu o cenário quase noturno da hora das Vésperas, o badalar dos sinos, o caminhar pela rua, a estrutura dialogal das máquinas e o desfecho no qual o poeta prossegue seu caminho e segue "avaliando o que perdera". O poema de Auden começa com os versos "As $i$ walked out one evening,/ Walking down Bristol Street [...]", ao passo em que o poema de Drummond inicia-se com os versos "E como eu palmilhasse, vagamente/uma estrada de Minas, pedregosa [...]". Cf.: Almeida (2020).

13 A metáfora do caminho é reiterada na argumentação de Camus em diversas passagens d'O Mito de Sísifo: "quero me desviar um pouco do caminho certo", "fui colocado no meio do caminho entre a miséria e o sol", "o homem absurdo procura seu caminho no meio dos escombros", etc. O termo "caminho" reaparece em vinte e nove (29) ocorrências ao longo do ensaio.
} 
os três interlocutores eleitos pelo itabirano — Jorge de Lima, Albert Camus e W. H. Auden — nos falam de um acontecimento extraordinário e revelador. Por isso, Drummond, a exemplo desses interlocutores, transforma uma caminhada cotidiana numa aventura metafísica ou, mesmo, numa experiência mística. Camus descreve essa metáfora do caminho do homem absurdo na seguinte passagem:

A certa altura do seu caminho o homem absurdo é solicitado. [...] Pede-se que ele salte [isto é, que tenha fé em Deus e aceite a esperança de uma vida eterna]. Tudo o que pode responder é que não compreende bem, que isso não é evidente. Quer fazer, justamente, aquilo que compreende bem. Asseguram-lhe que é pecado de orgulho [negar o salto para a fé], mas ele não entende a noção de pecado; [asseguram-lhe] que no final talvez esteja o inferno, mas ele não tem imaginação suficiente para vislumbrar esse estranho futuro; talvez perca a vida imortal, mas isso the parece fútil. Querem que reconheça sua culpa. Ele se sente inocente. Na verdade, só sente isto, sua inocência irreparável. É ela que lhe permite tudo. Assim, o que ele exige de si mesmo é viver somente com o que sabe, arranjar-se com o que é e não admitir nada que não seja certo [...] (CAMUS, 1989, p. 41, grifo do autor).

Ao narrar o encontro com a máquina do mundo, Drummond redesenha esse momento crucial de solicitação no qual o homem absurdo é posto diante da obrigação existencial de decidir. Decidir, enfatizou Camus, é "tornar-se um homem” (CAMUS, 1989, p. 63) ${ }^{14}$. No poema As I Walked Out One Evening, de W. H. Auden, o encontro do poeta-narrador com os amantes felizes e, posteriormente, com os relógios em homilia, não fora retratado pelo poeta inglês como existencialmente decisivo,

14 Como enfatizou o tradutor Mauro Gama, o título Le Mythe de Sisyphe soa no original francês como um trocadilho com Le mythe décisif (o mito decisivo). 
mas apenas como um acontecimento cotidiano ante a eternidade do tempo. No caso de Drummond e Camus, contrariamente, o homem absurdo é confrontado por uma oferta mística decisiva, reveladora de todos os enigmas do mundo. E esse encontro epifânico exige do poeta mineiro que ele escolha entre dar o salto rumo ao escuro místico da visão de Deus ofertada por Jorge de Lima, seu interlocutor oculto, ou "viver somente com o que sabe, arranjar-se com o que é e não admitir nada que não seja certo [...]" (CAMUS, 1989, p. 41). A aparição da máquina, portanto, exige que ele escolha entre a lucidez da razão resignada ao absurdo (sem apelo ou consolo) e a vida de fé, amparada, seja na aceitação de Deus como "explicação total da vida", seja na aceitação do homem triunfal, dominador dos recursos da Terra, senhor absoluto do mundo. Se Jorge de Lima é o anjo que oferece a Drummond a visão miraculosa da criação universal por obra divina, Camus é seu outro eu, aquele demônio do absurdo que se nega ao salto rumo ao divino porque prefere viver combativa e corajosamente nesse limbo onde não há certezas sobre o futuro e onde a visão beatífica de Deus é impossível. O homem absurdo, assim, decide viver no limbo dantesco e por isso está deliberada e conscientemente apartado da consolação divina.

Para além dessa imagem do caminho descrita n'O Mito de Sísifo, Camus nos fala também da fé como uma aparição ou epifania. No diálogo entre Meursault e o capelão, no último capítulo de O Estrangeiro (CAMUS, 2019a, p. 64), o padre refere-se a "uma face divina que sai da obscuridade" para os homens "mais miseráveis" que estão condenados à pena de morte. O poema de Drummond replica essa ideia da epifania de uma face divina oriunda de um lugar obscuro. O fato é que, mesmo ante a morte iminente e a possibilidade de um encontro 
com Deus, Meursault permanece corajosamente sem fé, assunto que afirma não despertar nele qualquer interesse, porque aceita o desamparo e não está desesperado (numa alusão a Kierkegaard). Afirma ainda que todos nós estamos - prisioneiros e homens livres - igualmente condenados à morte e que o medo é natural (numa alusão ligeira à distinção agostiniana entre tremer ante a morte, o que seria uma reação biológica natural, e temer a morte, o que seria uma inclinação espiritual). Meursault, portanto, vêse como um homem desamparado ante a realidade da morte iminente, mas mesmo assim não busca o consolo da fé. Camus, através da fala de Meursault, vê o desconsolo ante a morte, assim como a falta de esperança numa vida pos mortem, como um gesto de coragem e de aceitação combativa da finitude e da mortalidade. Nesse aspecto, o desejo pela vida eterna é para Meursault um desejo como outro qualquer, tal como o "desejar ser rico, nadar muito depressa ou ter uma boca mais bem feita [...]" (CAMUS, 2019a). O capelão, contrariamente, entende essa coragem de aceitar o desamparo, sem fé nem esperança, como um pecado de soberba impossível de ser suportado. De todo modo, Camus, Meursault e Drummond advogam uma mesma filosofia de vida. Ante essa face divina que sai da obscuridade e se mostra gratuitamente como uma solução fideísta para o problema da finitude humana, esses três homens absurdos têm como única resposta possível a recusa. Por analogia com o encontro entre Meursault e o capelão, podemos dizer que O Livro de Sonetos de Jorge de Lima exerceu sobre Drummond o mesmo papel que a admoestação do padre exercera sobre Meursault. Com a diferença de que o poder de encantamento exercido pela sublime poesia do bardo alagoano fora, provavelmente, mais tentador do que os conselhos do padre ao pied noir. 
Podemos dizer, numa palavra, que Drummond escreveu A Máquina do Mundo à luz da filosofia do absurdo de Albert Camus como um esforço de exorcizar, em si mesmo, o encanto provocado pela beleza mística dos poemas do Livro de Sonetos de Jorge de Lima. É muito provável que o poema tenha sido, todo ele, pensado e escrito como uma resposta frontal àquela visão mística da criação universal. Camus fora, para Drummond, um remédio amargo, porém necessário, prescrito com o intuito de expulsar as tentações da fé mística copiosamente exibida pelos poemas de Jorge de Lima.

Outra imagem (evidência 3) que Drummond incorpora da filosofia do absurdo de Camus está no tema da luz — advinda da própria máquina do mundo - que não emite "um clarão maior que o tolerável". Camus define o sentimento da absurdidade exatamente como uma "luz sem cintilação", "inapreensível": "Numa esquina qualquer, o sentimento do absurdo pode bater no rosto de um homem qualquer. Tal como é, em sua nudez desoladora, em sua luz sem brilho (dans sa lumière sans rayonnement), esse sentimento é inapreensível [...]" (CAMUS, $2019 b$, p. I., grifo nosso).

A imagem dessa luz fosca, fraca, é redesenhada por Drummond quando reaproveita de Camus esse tema do encontro com o absurdo "numa esquina qualquer". Nesse instante, a máquina do mundo "Abriu-se majestosa e circunspecta,/ sem emitir um som que fosse impuro/ nem um clarão maior que o tolerável". Tal imagem da luz sem brilho contrapõe-se à imagem mística da aparição divina (de Deus, Cristo, Maria, de um santo, ou anjo) aos homens de fé; para eles, os místicos como Jorge de Lima, a luz de tal epifania é fulgurante e intolerável para a visão humana. Seria a luz intensa da Glória ou da própria face de Deus. 
A contraposição entre as duas luzes - a fosca e a fulgurante, a fraca e a forte - é, portanto, a contraposição alegórica entre a luz mística da fé fervorosa de Jorge de Lima e a luz sem brilho, sem fé ou esperança, avistada pelo homem absurdo representado por Drummond. Por isso, Jorge de Lima relatou, acerca da sua experiência mística, estar "orgulhoso da luz que [o] cegou" (Soneto 5, p. 467, 1997).

A noção do absurdo descrita por Camus está alegoricamente representada, também, pela imagem do "mundo "espesso"" (evidência 4) na seguinte passagem d'O Mito de Sísifo: “[...] dar-se conta de que o mundo é 'espesso' (épais), entrever até que ponto uma pedra é estranha, nos é irredutível [...] Essa espessura (épaisseur) e essa estranheza do mundo é o absurdo [...]" (CAMUS, 1989, p. 15). Essa noção do absurdo como "espessura" e "estranheza" é replicada por Drummond ao se referir à "treva espessa" conforme aparece nos tercetos abaixo:

\author{
Mas, como eu relutasse em responder \\ a tal apelo assim maravilhoso, \\ pois a fé se abrandara, e mesmo o anseio, \\ a esperança mais mínima - esse anelo \\ de ver desvanecida a treva espessa \\ que entre os raios do sol inda se filtra [...]
}

(DRUMMOND, 2002, p. 303, grifo meu)

A esperança é o anelo de ver desvanecida a "treva espessa", ou seja, ver desvanecido o sentimento do absurdo que divorcia o homem do mundo e impõe-lhe a sensação de estranhamento e não pertença. A treva espessa, portanto, é essa percepção do mundo como algo que nos é estranho; irredutível, ela é parte da própria condição humana. Afinal, para o absurdista somos todos 
estrangeiros neste mundo. $\mathrm{O}$ homem de fé, em contraposição a esse homem absurdo, tem desejo de unidade, exigência de clareza e coesão, crença na possibilidade de conhecer o sentido do mundo, além de julgar que tal sentido é redutível a um princípio racional. Tais anelos estorvam a consciência do absurdo. Como poetiza Drummond, este é "o anelo de ver desvanecida a treva espessa”. Anelo que o poeta, co-habitado por outro eu, recusa.

Quanto à "treva mais estrita", aquela que pousou sobre a estrada de Minas após a aparição da máquina do mundo ("A treva mais estrita já pousara/ sobre a estrada de Minas, pedregosa"), esta designa tão somente o anoitecer, tal como no poema de Auden ao assinalar que "Era tarde, tarde e anoitecia" ("It was late, late in the evening"). O poema de Drummond, assim como o de Auden, transcorre entre o "fecho da tarde", à tardinha, e o baixar da treva estrita da noite, à noitinha. Essa hora das Vésperas narrada por Auden em As I Walked Out One Evening fora replicada por Drummond. Ambos são poemas vesperais, crepusculares.

Outra metáfora camusiana engastada por Drummond em A Máquina do Mundo é a imagem do deserto (evidência 5) como representação pictórica do pensamento que aceita o absurdo e o irracional como constituintes da realidade, do sentido da vida e do mundo. É, portanto, a aceitação desse sem-sentido. A imagem desértica está contraposta aí à imagem da aceitação de Deus como "explicação total da vida". No poema, Drummond nos fala da exaustão dos sentidos que cansaram de "mentar" no "deserto" em busca de uma "realidade que transcende" a "própria imagem sua debuxada". Eis aí o esforço do homem absurdo que tenta entender a ausência de sentido do mundo e da vida, ou seja, tenta pensar em meio à aridez inóspita do deserto. Quando a máquina 
do mundo aparece para tal homem, ele se diz exausto de fazer esse esforço sobre-humano de compreensão dos desertos do absurdo. Suas "pupilas" foram "gastas na inspeção/ contínua e dolorosa do deserto"; sua cabeça está "exausta de mentar/ toda uma realidade que transcende/ a própria imagem sua debuxada/ no rosto dos mistérios, nos abismos". O absurdo é, para ele, um desses "lugares desertos e sem água onde o pensamento atinge os seus confins" (CAMUS, 1989, p. 12), porque é no deserto que o "pensamento" encontra "seu pão" (CAMUS, 1989, p. 20).

Nesse aspecto, Camus nos adverte que não é o absurdo que nos impõe a necessidade de Deus, como afirmam alguns pensadores de fé, mas a covardia do espírito que se nega a suportar o peso da ausência de sentido da vida. O homem absurdo reconhece a própria "impotência de compreender o ser que ilumina tudo" (CAMUS, 1989, p. 28). Por isso, a afirmação de Deus como necessidade seria um "salto" que negaria a lógica e a própria "lucidez humana". Aceitar a noção do absurdo seria um gesto de coragem e lucidez de quem que não admite para si um "trampolim para a eternidade" (CAMUS, 1989, p. 30). Portanto, viver nos desertos do absurdo significa negar a si, asceticamente, esse "apetite de familiaridade ou desejo de clareza" (CAMUS, 1989, p. 38), isto é, significa negar-se a abandonar o caminho da evidência. $\mathrm{O}$ homem esperançoso da vida eterna não pode compreender o lugar desconfortável e deserto a partir do qual o sentimento do absurdo se desenvolve.

Daí que a noção do absurdo não se confundiria com a aceitação de Deus como solução para os limites da razão, tampouco admite, tal como pregara Santo Ignácio de Loyola, "o sacrifício do intelecto" (CAMUS, 1989, p. 31), a loucura cristã-paulina como superação do logos. O absurdo é o "estado 
metafísico do homem consciente", logo, "não conduz a Deus" porque é "o pecado sem Deus" (CAMUS, 1989, p. 33). E como não há cura para esse mal, é preciso aprender a viver e conviver com ele. Aceitar o absurdo significa viver sem o consolo da fé em Deus. Logo, considerar o absurdo uma verdade inescapável é o mesmo que aprender a pensar no deserto do absurdo:

Se considero verdadeira essa absurdidade que rege minhas relações com a vida, se me compenetro desse sentimento que se apossa de mim ante o espetáculo do mundo, dessa clarividência que me impõe a busca de uma ciência, devo sacrificar tudo a tais certezas e encará-las de frente para poder mantê-las [...] Falo aqui de honestidade. Mas quero saber, antes, se o pensamento pode viver nesses desertos (CAMUS, 1989, p.20).

Por isso a metáfora ou imagem do deserto está intrinsecamente ligada a essa "realidade que transcende" a razão humana (evidência 6). O poeta-narrador tem as "pupilas gastas na inspeção/ contínua e dolorosa do deserto", assim como tem "a mente exausta de mentar/ toda uma realidade que transcende". Igualmente, o espírito absurdo sabe que há uma realidade que o transcende, que o ultrapassa. Ele sabe que "[t]oda a ciência desta Terra não me dirá nada que me assegure que este mundo me pertence. [...] a ciência que deveria me ensinar tudo acaba em hipótese, a lucidez sombria culmina em metáfora, a incerteza se resolve em obra de arte [...]" (CAMUS, 2019b, p. I.)

Essa realidade que transcende a condição humana é inapreensível e o homem absurdo reconhece, exausto e combativo, que não pode aceder a ela com os subterfúgios da crença em Deus ou da esperança na vida eterna. Por isso, diz Camus, "para um homem sem antolhos não há espetáculo mais belo que o da inteligência às voltas com uma realidade que $o$ 
transcende (dépasser) [...]" (CAMUS, 1989, p. 42). Noutra passagem, retrata o rosto e a alma desse homem nos seguintes termos: "Esse rosto a um tempo terno e escarnecedor, essas piruetas seguidas de um grito que vem do fundo da alma, é o próprio espírito absurdo às voltas com uma realidade que $o$ transcende (dépasse) [...]" (CAMUS, 1989, p. 23, grifo nosso). Portanto, o sentimento do absurdo, mais do que uma mera impressão, nasce de uma comparação entre um "estado de fato" e o "mundo que o transcende". ${ }^{15}$

Portanto, o homem absurdo se vê diante de uma realidade transcendente cuja compreensão ultrapassa os limites cognitivos da razão humana. Como não tem fé, esse homem se nega a buscar em Deus um subterfúgio ou consolação. Ele aceita carregar em si o peso do "absurdo original e seus enigmas". Ao admitir tal peso, a consciência desse homem se nega a ter "a esperança de outra vida que é preciso 'merecer' [...]” (CAMUS, 1989, p. 11).

Dentre os princípios da "noção do absurdo" como filosofia está o ato de negar a vitalidade das esperanças da razão (e não apenas a esperança numa vida eterna). Drummond responde silentemente à máquina como alguém que não tem paixão por tal decifração ou desvelamento "da ordem geométrica de tudo". O homem absurdo que passa a comandá-lo ante o desvelamento do mistério ofertado pela máquina, tal como ocorrera com Meursault ante as interpelações do capelão, "recusa as consolações, a moral, os princípios de todo repouso e nada faz para abrandar a dor desse espinho que sente no coração [...]" (CAMUS, 1989, p. 23).

\footnotetext{
15 "Tenho base, portanto, para dizer que o sentimento da absurdidade não nasce do simples exame de um fato ou impressão, mas que ele brota da comparação entre um estado de fato e uma certa realidade, entre uma ação e o mundo que a transcende (dépasse) [...]" (CAMUS, 1989, p. 26, grifo nosso). No original: "la comparaison entre un état de fait et une certaine réalité, entre une action et le monde qui la dépasse [...]" (CAMUS, 2010, p. 33).
} 
Assim chegamos ao tema da esperança enquanto virtude antitética ao sentimento do absurdo (evidência 7), isto é, o tema da recusa da esperança, substituída pela indiferença ante o futuro depois da morte. Como "o absurdo é o contrário da esperança" (CAMUS, 1989, p. 29), o homem absurdista sabe que deve extrair de si a coragem de negar o eterno, deve aprender a viver sem o amparo de qualquer "metafísica de consolação" (CAMUS, 1989, p. 29). Assim, o sentimento do absurdo que o move faz com que a "razão lúcida constate os seus [próprios] limites [...]" e os suporte (CAMUS, 1989, p. 38). A esperança numa vida eterna por merecimento pessoal se desvanece em meio a essa "treva espessa" que aparta o homem de seu mundo.

Drummond, nessa lógica, se declara apartado da "esperança mais mínima" de ver "desvanecida a treva espessa" que é a percepção do absurdo. Por isso, ao avistar a "coisa oferta" pela máquina do mundo, o poeta a recusa, porque aceitá-la significaria saltar para os consolos da esperança, da fé irracional ou da razão científica triunfal. Carlos e Camus entendem que "o absurdo é a razão lúcida que constata os seus limites" (CAMUS, 1989, p. 38); enfrentar os desertos do absurdo requer que se aprenda a viver sob o regime da "oposição, dilaceração e divórcio" (CAMUS, 1989, p. 30) entre o homem e o sentido da vida. Quando Drummond decide recusar as oferendas da máquina e "segue vagaroso, de mãos pensas" ele o faz porque:

O homem absurdo vislumbra um universo ardente e gélido, transparente e limitado, no qual nada é possível mas tudo está dado, depois do qual só há o desmoronamento e o nada. Pode então decidir aceitar a vida em semelhante universo e dele extrair suas forças, sua recusa à esperança e o testemunho obstinado de uma vida sem consolo. Mas o que significa a vida em semelhante universo? Por ora, apenas a indiferença 
pelo futuro e a paixão de esgotar tudo o que é dado [...] (CAMUS, 1989, p. 46).

Depois da recusa, "só há o desmoronamento e o nada" (CAMUS, 1989, p. 46), isto é, uma vida conduzida tanto pela "indiferença" em relação ao "futuro", quanto pela "paixão de esgotar tudo o que é dado", já que para o homem absurdo "todas as experiências são indiferentes" (CAMUS, 2019b). Essa indiferença é magistralmente figurada por Drummond na imagem do poeta que segue seu caminho com o andar "vagaroso, de mãos pensas".

N'O Estrangeiro, Camus descreve a recusa à esperança como uma espécie de sentimento triunfal que acomete Meursault após a confrontação final com o capelão. Ali, o narrador relata que "vazio de esperança, [Meursault] se abriu pela primeira vez à terna indiferença do mundo [...]" (CAMUS, 2019a, p. 65). Assim como Meursault se recusou a ter fé e esperança na vida eterna, a despeito da pregação insistente do capelão, Drummond se recusou a "agasalhar" em seu peito toda a ciência "sublime e formidável" ofertada pela máquina. Mersault e Carlos se autocompreenderam, desde então, como estrangeiros da fé.

Por isso, a aparição da máquina, mais do que uma oferenda, pode ser compreendida como um confronto hipotético no qual o homem absurdo rejeita não só a fé nos poderes da ciência como força dominadora dos recursos da Terra, mas também a fé em Deus (criador do universo e portador da "explicação total da vida"). Tanto o entusiasta da ciência quanto o homem de fé têm, igualmente, desejo de clareza. Por isso, Camus nos explica que o sentimento do absurdo "nasce desse confronto [...] entre o apelo humano e o silêncio sem propósito do mundo [...]" (CAMUS, 1989, p. 24), ou melhor, nasce do confronto entre "este irracional 
e o desejo apaixonado de clareza cujo apelo ressoa no mais profundo do homem [...]" (CAMUS, 1989, p. 20). Nem a fé em Deus, nem a fé na ciência podem seduzir ou tentar esse homem. Ele está desdenhosamente resoluto em sua recusa. Perdeu toda a esperança na vida eterna.

Assim é que o tema da recusa à "explicação total da vida" constitui outra evidência (a oitava) da simbiose vital entre o narrador de A Máquina do Mundo e o filósofo de $\mathrm{O}$ Mito de Sísifo. Tal tema aparece, inicialmente, como motivo de riso do homem honesto: "Essa razão universal - moral ou prática -, esse determinismo, essas categorias que explicam tudo têm com que fazer rir o homem honesto.”. (CAMUS, 1989, p. 20, grifo nosso).

Para melhor compreender a natureza da recusa ${ }^{16}$ devemos primeiramente distingui-la da renúncia. Como enfatizou Camus, a recusa não é uma renúncia, porque renunciar pode conduzir o homem ao suicídio, à negligência ou à fuga. Logo, a renúncia só pode nos dar uma "paz envenenada" (CAMUS, 1989, p. 19). A recusa, por sua vez, é o não. O homem absurdo decide não saltar para a eternidade, não aceitar a fé em Deus, não ter esperança na vida eterna, não se preocupar com o futuro, não se iludir com os poderes da ciência, não ultrapassar os limites da lucidez e da razão imanente, não usar o suicídio como fuga ante o peso da realidade absurda.

Ainda que a recusa seja o "não", ela também sabe dizer "sim". Por isso, o homem absurdo deve impor sobre si próprio uma

16 O livro de Betina Bischof (2005), supreendentemente, não associa o tema da recusa, conforme narrado em A Máquina do Mundo, com a filosofia do absurdo de Albert Camus. O pensador franco-argelino (CAMUS, 2010) emprega termos como "refuser", "refusant", "refuse", "refus" e "refusèrent" em vinte e sete (27) passagens d'O Mito de Sísifo (CAMUS, 1989). Fala em "ter paz com a recusa de saber e viver" (p.19), "recusa as consolações, a moral" (p.23), "recusa contínua" (p.27), "recusa a explicar o mundo" (p.34), "pensamento que se recusa a explicar" (p.35), "recusa da morte" (p.42), "recusa à espera" (p.46), "recuso o suicídio" (p.48), "recusa a só viver um destino" (p.60), etc. Drummond, como sabemos, não usa o termo "recusa" no poema, apenas sugere sua relutância em aceitar a "coisa oferta" pela máquina ("e como eu relutasse em responder"). Assim, declara-se "incurioso", "lasso" e "desdenhoso" ante aquele "dom tardio" e "gratuito" que àquela altura parecia-lhe "despiciendo". De todo modo, a recusa de Drummond é, ao que tudo indica, a mesma recusa reiterada na filosofia do absurdo de Camus. 
"disciplina do espírito" que o habilite a manter sua inteligência em permanente luta contra a realidade que o transcende. Essa é a luta que verdadeiramente o engrandece. Em contraposição, o que o apequena são as doutrinas da "explicação total da vida". Elas devem ser negadas não apenas porque enfraquecem e empobrecem a dignidade do homem, mas, sobretudo, porque o desobrigam de suportar sozinho o fardo do absurdo. É o que nos diz Camus na seguinte passagem: "[...] compreendo então porque as doutrinas que me explicam tudo, ao mesmo tempo, me enfraquecem. Elas me descarregam do peso da minha própria vida e, no entanto, preciso carregá-lo sozinho [...]" (CAMUS, 1989, p. 42, grifo nosso).

Essa aceitação do peso do absurdo, como podemos perceber, traz consigo um elemento cético que pode confundir o homem e induzi-lo ao suicídio. Por isso, Camus se prontifica no intuito de desfazer tal imbróglio. "O suicida resolve o absurdo", diz o argelino. Suicidar-se é fugir do fardo vital da luta. Mas "o absurdo não pode se resolver porque ele é, ao mesmo tempo, consciência e recusa da morte [...]" (CAMUS, 1989, p. 42). A luta da inteligência contra a realidade transcendente não tem solução. Logo, o caráter irredutível da luta não deve "se aliar a uma moral da renúncia". Recusar não é o mesmo que se entregar à morte. Renunciar, sim. Daí que a relação do homem com a realidade deve ser pensada como "uma confrontação e uma luta sem descanso" (CAMUS, 1989, p. 27). Este enfrentamento ante a: “[...] lógica absurda [...] pressupõe a total ausência de esperança (que nada tem a ver com o desespero), a recusa contínua (que não deve ser confundida com a renúncia) e a insatisfação consciente (que não se poderia associar à inquietude juvenil) [...]" (CAMUS, 1989, p. 27). Portanto, a "lógica do absurdo" 
não deve ser confundida com o desespero, nem com a renúncia, tampouco com a inquietude juvenil. O que a caracteriza é a confrontação e a luta incansável do homem, que deve manter-se em permanente recusa. Por isso, Camus nos explica que:

Consciência e revolta: essas recusas são o contrário da renúncia. Tudo o que há de irredutível e apaixonado num coração humano as estimula [...]. Trata-se de morrer irreconciliado, não de boa vontade. O suicídio é um irreconhecimento. O homem absurdo só pode esgotar tudo, e se esgotar. O absurdo é sua tensão extrema, a que ele mantém constantemente com um esforço solitário, porque sabe que nessa consciência e nessa revolta de cada dia ele testemunha sua única verdade, que é o desafio. (CAMUS, 1989, p. 43).

Quando Drummond recusa a "coisa oferta" sua negativa se assemelha mais a uma resolução pessoal e menos a um gesto de combate. O poeta não se autodescreve como alguém que triunfou sobre as verdades sagradas que lhe foram oferecidas, tampouco se dispõe a adorar alguma verdade filosófica sobressalente. Ele apenas recusa a oferta, indiferente, porque está cansado da busca por clareza que não mais o apraz. Está exausto, sereno e resoluto em sua desistência. Já esgotou todas as possibilidades de aceder ao ser e se esgotou nesta lida. Daí o gesto de desdém ante esse "dom tardio", desdém esse figurado nos atos de "baixar os olhos, incurioso, lasso" e "seguir" seu caminho pessoal "vagaroso, de mãos pensas". Elejá era, àquela altura, "um homem sem esperança e consciente de sê-lo", por isso, não mais the "pertencia o futuro" (CAMUS, 1989, p. 27). Drummond, assim, "sustent[ou] a aposta dilacerante e maravilhosa do absurdo [...] para [então] reencontrar o vinho do absurdo e o pão da indiferença com que alimenta sua grandeza [...]" (CAMUS, 1989, p. 41). 
Como sabemos, Drummond não usa a palavra "recusa" para descrever sua decisão, porém, emprega a palavra "lasso" (evidência 9). O tema da lassidão ("lassitude") aparece n'O Mito de Sísifo como um "movimento da consciência" que "desperta" e passa a se perguntar pelo "por quê" da vida (CAMUS, 2010, p. I). Após semanas de repetição rotineira dos afazeres cotidianos, dias transcorridos "sem problemas a maior parte do tempo", divididos entre o trabalho, as refeições e o sono, "um belo dia surge um por quê e tudo começa a entrar numa lassidão tingida de assombro [...]" (CAMUS, 2010, p. I). A lassidão, portanto, ocorre após a interrupção dessa "vida maquinal" na qual o homem se move mecanicamente sem pensar no sentido de suas ações repetitivas e circulares:

A lassidão está ao final dos atos de uma vida maquinal, mas inaugura ao mesmo tempo um movimento da consciência. Ela o desperta e provoca sua continuação. A continuação é um retorno inconsciente aos grilhões, ou é o despertar definitivo.[...] Em si, a lassidão tem algo de desalentador. Aqui devo concluir que ela é boa. Pois tudo começa pela consciência e nada vale sem ela [...] (CAMUS, 2019b, p. I). ${ }^{17}$

Segundo Camus, a lassidão se manifesta a partir da interrupção da vida maquinal e rotineira; ela "inaugura" "um movimento da consciência" em direção ao absurdo, mas também pode se manifestar como um lapso que interrompe as tarefas da vida cotidiana sem libertar o homem dos "grilhões" que o aprisionam na rotina. Nada garante que o homem, tocado pela lassidão, possa "despertar" em "definitivo" de sua vida maquinal inconsciente. Ainda assim, "ela é boa" porque pode eventualmente inaugurar o despertar da consciência para $o$ absurdo.

17 Nesta citação demos preferência à tradução de Ari Roitman e Paulina Watch porque a versão de Mauro Gama traduz "lassitude" por "cansaço". 
Como sabemos, Drummond conclui o poema descrevendo a si mesmo como "incurioso, lasso". Nesse caso, a lassidão seria o efeito imediatamente posterior à decisão de recusar. A recusa é a mantença da disposição para lutar e suportar o absurdo; a lassidão é o despertar da consciência que passa a se movimentar pelos desertos do absurdo até que atinja os limites da autoconsciência. Se a lassidão é desalentadora, a recusa é a disposição espiritual para a luta e para a mantença do não. De todo modo, no caso de Drummond, tanto a recusa quanto a lassidão inauguraram o "movimento da consciência" do poeta em direção a sua autocompreensão como homem absurdo.

Nesta lógica, a aparição da máquina, ao interromper o movimento mecânico da vida rotineira do narrador, deu início ao movimento de autoconsciência. Decidido, resoluto e desdenhoso ante a oferta, o poeta baixou os olhos em sinal de recusa. Passou então a compreender que tal "dom tardio" já não the era "apetecível", mas, "antes despiciendo". Toda a coisa oferta, àquela altura, lhe era indiferente. Daí que a lassidão, naquele instante, designasse essa continuação do movimento da consciência que escolheu não mais retornar aos grilhões da vida cotidiana, mas permanecer definitivamente desperta para o absurdo da falta de sentido da vida. Assim, Drummond nos esclareceu que aquela experiência epifânica o deixou lasso, isto é, desperto e consciente, ainda que desalentado.

Já a metáfora da "neutra face" (evidência 10) é descrita por Camusn'OEstrangeiromediante ouso de outras palavras tais como "insensibilidade", "ausência de emoção", "falta de humanidade no coração", "coração vazio" e homem "monstruoso". Estas palavras, em geral, são postas à boca do procurador que acusa Meursault, durante o julgamento, do "crime" de indiferença ante 
a morte da mãe. No poema de Drummond a "neutra face" designa a indiferença ante as "defuntas crenças convocadas" pelo próprio poeta numa tentativa de novamente "tingir" seu rosto com a face positiva da fé (em Deus ou na Ciência) e, finalmente, se abrir à recepção daquele "tal apelo assim maravilhoso"18. Essa "neutra face" que o narrador vai "pelos caminhos demonstrando", face de um homem de "fé branda", "sem anseio" e "sem esperança", é, portanto, a mesma face neutra de Meursault, um homem sem emoções, mesmo diante da notícia da morte da própria mãe. Sua condenação fora agravada pelo fato de não demonstrar comoção ou vontade de chorar no funeral da mãe. Afinal, para o júri, reagir com indiferença no enterro da própria mãe era mais repugnante moralmente do que matar alguém. A incapacidade de sentir remorso ou demonstrar emoções em público era a prova de que Meursault deveria ser punido com a pena de morte. Ser um homem de face neutra é mais condenável moralmente do que ser um assassino.

Quando reage emotivamente, Meursault o faz contra os apelos para que tenha fé na salvação, como podemos testemunhar no diálogo tenso com o capelão da penitenciária. No poema de Drummond, a "neutra face" designa a figuração encarnada dos nãos da recusa: fé e esperança brandas, ausência de qualquer anseio ante o futuro, descrença na vida eterna e na salvação da alma. Sabemos que Jorge de Lima fora o místico que, involuntariamente, ofereceu ao homem de "neutra face" uma visão do mistério da criação divina em língua poética perfeita, por isso, mais tentadora para Drummond do que fora a narrativa de Camus, na qual o capelão insiste para que Meursault tenha fé e se converta antes da morte. Por isso, Jorge de Lima estaria para

18 Drummond alude aqui à alegoria das maravilhas, cuja origem remonta ao Livro das Maravilhas de Marco Polo, mas que reaparece, também, n'Os Lusíadas. Cf. Vítor Aguiar e Silva (2011), p.559-565. 
Drummond assim como o capelão estaria para Meursault.

Ademais, Drummond se autorretrata como um homem "noturno e miserável", tão obscuro interiormente a ponto de difundir sua escuridão pelos montes. Nessa metáfora (evidência 11), o poeta nos deixa entrever o tema camusiano da noite como um símbolo do pensamento absurdo que busca, na escuridão noturna e sem o subterfúgio dos místicos cristãos, uma "vigília do espírito". Assim, Camus distingue a noite dos místicos, que é uma fuga da realidade difícil do absurdo, e a noite do homem absurdo, que é uma vigília lúcida do espírito:

"A prece" - diz Alain — "é quando a noite cai sobre o pensamento". "Mas é preciso que o espírito torne a encontrar a noite", respondem os místicos e os existencialistas. Certo, mas não a noite que nasce diante de olhos fechados e por exclusiva vontade do homem - noite sombria e fechada que o espírito suscita para nela se perder. Se ele precisa encontrar uma noite, que seja aquela do desespero que permanece lúcido, noite polar, vigília do espírito, da qual se erguerá talvez a clareza branca e intacta que desenha cada objeto à luz da inteligência [...] (CAMUS, 2019b, p. I).

Rezar, dizem os místicos, como São João da Cruz, é fazer cair a noite sobre o pensamento. Mas essa noite dos místicos, tal como a noite dos existencialistas, é própria daqueles que se fecharam para a realidade do absurdo; é a noite dos que decidiram se evadir da luta. Em contraposição, a noite do homem absurdo é aquela que se mantém lúcida e aberta aos apelos de uma razão orgulhosa de si. Vemos aí a oposição entre os homens de olhos fechados e os homens despertos para vigília da noite. Homens e flores, em si mesmos abertos e fechados, como poetizou Drummond. Camus assim nos explica que a consciência da própria ignorância é a noite que o homem absurdo carrega dentro 
de si, e a difunde. Por isso, enfatiza: "Essa noite é minha luz [...] Pergunto o que acarreta a condição que reconheço como sendo minha, sei que ela compreende obscuridade e ignorância, mas me garantem que essa ignorância explica tudo e que essa noite é a minha luz." (CAMUS, 1989, p. 33).

O pensador argelino nos adverte aí que a condição do absurdo contém em si "obscuridade e ignorância", mas uma "ignorância que explica tudo". Como se explica esse paradoxo entre a lucidez da razão imanente e a ignorância obscura que a constitui? Segundo Camus, "o absurdo é o pecado sem Deus" (CAMUS, 1989, p. 33), ou seja, é o pecado da inteligência que se nega a "sacrificar seu orgulho" e sua "razão" em nome de uma fé transcendente. Quer dizer, o absurdo nega-se a construir verdades "em cima do incompreensível" (CAMUS, 1989, p. 32). Da perspectiva de um cristão místico, o homem absurdo está em pecado de orgulho. Não obstante, esse homem reconhece os "limites da razão", mas não "ao ponto de negá-la", porque admite os poderes relativos de tal faculdade. Este é o "estado metafísico do homem consciente" e sua inteligência clara que se mantém "nesse caminho médio" que não conduz a Deus. Estar em tal caminho médio significa viver entre a lucidez clara da razão imanente e a obscuridade penumbrosa da ignorância que reconhece os limites de tal razão. Esta é a zona cinzenta onde vive o homem absurdo.

\section{Conclusão}

Dadas tais evidências, parece-nos plausível sustentar a tese de que há, de fato, uma relação intertextual entre as metáforas expostas em A Máquina do Mundo e as metáforas descritas 
n’O Mito de Sísifo. Movido por uma disposição dramática e existencial, Drummond se fez porta-voz da filosofia absurdista. Em verdade, tudo indica que o poeta se propôs empreender uma "obra absurda" segundo os princípios postulados pelo próprio Camus. Mas o que seria, afinal, essa "obra absurda"? Segundo o pensador argelino:

Para que seja possível uma obra absurda, é preciso que o pensamento esteja amalgamado com ela em sua mais lúcida forma. Mas é preciso, ao mesmo tempo, que ele não apareça nela senão como a inteligência que organiza. Esse paradoxo se explica de acordo com o absurdo. A obra de arte nasce da renúncia da inteligência a raciocinar sobre o concreto. Ela assinala o triunfo do carnal. É o pensamento lúcido que a origina, mas nesse próprio ato ela se desprende. Não cederá à tentação de sobrepor ao descrito um sentido mais profundo que ela sabe ilegítimo. A obra de arte encarna um drama da inteligência, mas só indiretamente apresenta a sua prova. A obra absurda exige um artista consciente desses limites e uma arte em que o concreto não significa nada mais do que ele próprio. (CAMUS, 1989, p. 71).

O princípio geral da criação artística, afirma Camus, é que "a obra de arte nasce da renúncia da inteligência [...]" que se põe a "raciocinar sobre o concreto". Dado esse princípio, a obra absurda torna-se "possível" na medida em que o artista aceita as regras de criação que a regem: o pensamento absurdo, "em sua forma mais lúcida", deve estar amalgamado à obra absurda sem se tornar visível senão como uma inteligência que organiza previamente a criação artística. Esse aparente paradoxo — de um pensamento que deseja ser encarnado numa obra de arte sem se tornar imediatamente visível nela — se resolve se o artista criador souber ser discreto e se dispuser a guardar segredo, já que "não há verdadeira criação sem segredo [...]" (CAMUS, 1989, p. 82). 
Em última instância, o que o encontro epifânico descrito no poema de Drummond nos revela é um "drama da inteligência". E a compreensão desse drama só é possível se o expectador for capaz de perceber como o artista, consciente dos limites da sua criatividade, pode renunciar à sua própria inteligência a fim de dar voz a uma inteligência capaz de melhor guiá-lo. Como assinala Camus: "A obra encarna um drama intelectual. A obra absurda ilustra a renúncia do pensamento a seus encantos e sua resignação a não ser mais do que a inteligência que converte em trabalho as aparências e cobre de imagens o que não é racional." (CAMUS, 1989, p. 71).

O poema de Drummond, como obra de arte absurda, encarnou-se nas imagens do caminho e da aparição epifânica de uma máquina porque as experiências comuns expressas por essas imagens não poderiam ser racionalmente explicadas pela inteligência puramente filosófica. Desse encontro entre a Arte e a Filosofia se fez "a obra do artista absurdo", aquela que "encarn[ou] um drama intelectual [...]" (CAMUS, 1989, p. 71). Daí que todas as replicações metafóricas e imagéticas feitas por Drummond se devam, de algum modo, à aplicação desses princípios absurdistas. A metáfora do caminho como autodescoberta, a noite como paisagem interior do homem absurdo, a aparição da máquina e sua luz sem cintilação, o aprendizado da vida nos desertos do absurdo, a neutra face de um homem de fé branda, o esforço vão e exaustivo de aceder a uma realidade transcendente na qual a esperança fizesse sentido, a recusa à explicação total da vida como um gesto de coragem e combate, a lassidão como o despertar da consciência do homem até então imerso em sua vida maquinal, todas essas metáforas traduzem a resignação do artista criador ante a inteligência que o 
guia. Camus foi o Virgílio de Drummond nesta jornada. Assim, podemos resumir essas evidências intertextuais no seguinte quadro abaixo:

\section{A MÁQUINA DO MUNDO E O MITO DE SÍSIFO: EVIDÊNCIAS INTERTEXTUAIS}

\begin{tabular}{|c|c|c|}
\hline 1. & $\begin{array}{l}\text { "e como se outro ser, não } \\
\text { mais aquele/ habitante de mim } \\
\text { há tantos anos, / passasse a } \\
\text { comandar minha vontade [...]" }\end{array}$ & $\begin{array}{l}\text { "Em que medida o ator se beneficia } \\
\text { desses personagens, é difícil dizer. } \\
\text { Mas o importante não está aí. Trata-se } \\
\text { de saber, apenas, até que ponto ele se } \\
\text { identifica comessas vidas insubstituíveis } \\
\text { [que interpreta]. Acontece, realmente, } \\
\text { que ele as transporta consigo [...]". } \\
\text { (CAMUS, 1989, p.58). }\end{array}$ \\
\hline 2. & $\begin{array}{l}\text { "E como eu palmilhasse } \\
\text { vagamente/ uma estrada } \\
\text { de Minas, pedregosa, / e no } \\
\text { fecho da tarde [...] a máquina } \\
\text { do mundo se entreabriu/ [...] } \\
\text { Abriu-se em calma pura, e } \\
\text { convidando/ quantos sentidos e } \\
\text { intuições restavam". }\end{array}$ & $\begin{array}{l}\text { "A certa altura do seu caminho o } \\
\text { homem absurdo é solicitado. [...] } \\
\text { Pede-se que ele salte [isto é, que tenha } \\
\text { fé em Deus e aceite a esperança de uma } \\
\text { vida eterna]. Tudo o que pode responder } \\
\text { é que não compreende bem, que isso } \\
\text { não é evidente" (CAMUS, 1989, p.41). } \\
\text { "sei também que os mais miseráveis de } \\
\text { vós viram sair da obscuridade uma } \\
\text { face divina. É esta face que lhe pedem } \\
\text { para ver" (CAMUS, 2019b, p.64). }\end{array}$ \\
\hline 3. & $\begin{array}{l}\text { "Abriu-se majestosa e } \\
\text { circunspecta,/ sem emitir um } \\
\text { som que fosse impuro/ nem um } \\
\text { clarão maior que o tolerável // } \\
\text { pelas pupilas gastas". }\end{array}$ & $\begin{array}{l}\text { "Numa esquina qualquer, o sentimento } \\
\text { do absurdo pode bater no rosto de um } \\
\text { homem qualquer. Tal como é, em sua } \\
\text { nudez desoladora, em sua luz sem brilho } \\
\text { ('dans sa lumière sans rayonnement')" } \\
\text { (CAMUS, 2019). }\end{array}$ \\
\hline 4. & $\begin{array}{l}\text { "esse anelo/ de ver desvanecida } \\
\text { a treva espessa/ que entre os } \\
\text { raios do sol inda se filtra". }\end{array}$ & $\begin{array}{l}\text { “dar-se conta de que o mundo é } \\
\text { 'espesso' (épais), entrever até que ponto } \\
\text { uma pedra é estranha, nos é irredutível } \\
\text { [...] Essa espessura (épaisseur) e essa } \\
\text { estranheza do mundo é o absurdo" } \\
\text { (CAMUS, 1989, p.15). }\end{array}$ \\
\hline
\end{tabular}




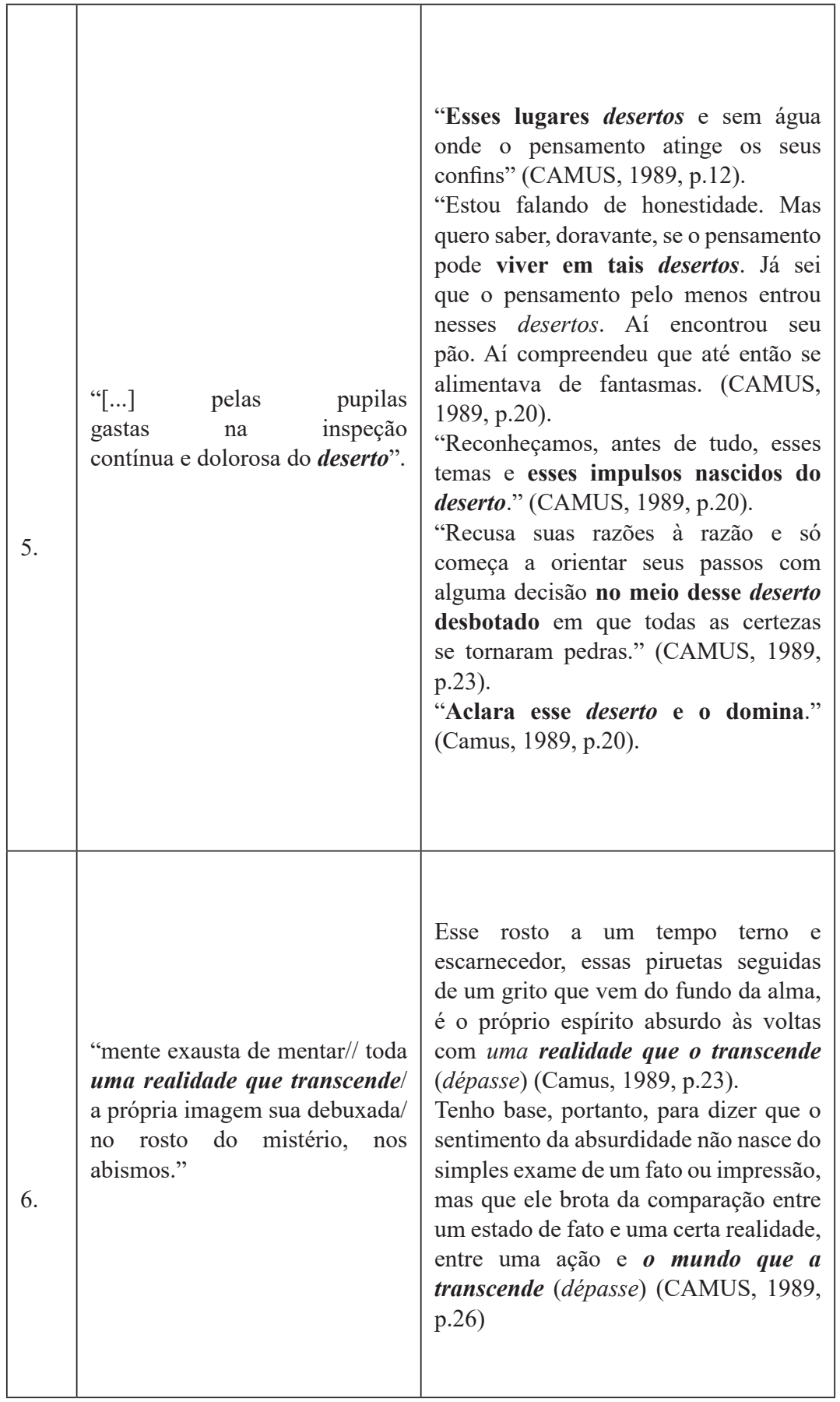




\begin{tabular}{|c|c|c|}
\hline 7. & $\begin{array}{l}\text { "pois a fé se abrandara, e mesmo } \\
\text { o anseio, // a esperança mais } \\
\text { mínima". }\end{array}$ & $\begin{array}{l}\text { "o absurdo é o contrário da esperança" } \\
\text { (CAMUS, 1989, p.29)". } \\
\text { "A lógica absurda [...] pressupõe a total } \\
\text { ausência de esperança (que nada tem a } \\
\text { ver com o desespero)" (CAMUS, 1989, } \\
\text { p.27). } \\
\text { "O homem absurdo vislumbra um } \\
\text { universo [...] no qual nada é possível } \\
\text { mas tudo está dado, depois do qual só há } \\
\text { o desmoronamento e o nada. Pode então } \\
\text { decidir aceitar a vida em semelhante } \\
\text { universo e dele extrair suas forças, sua } \\
\text { recusa à esperança e o testemunho } \\
\text { obstinado de uma vida sem consolo". } \\
\text { (CAMUS, 1989, p.46). }\end{array}$ \\
\hline 8. & $\begin{array}{l}\text { "essa ciência// sublime e } \\
\text { formidável, mas hermética,// } \\
\text { essa total explicação da vida". }\end{array}$ & $\begin{array}{l}\text { Essa razão universal - moral ou prática } \\
\text {-, esse determinismo, essas categorias } \\
\text { que explicam tudo têm com que fazer } \\
\text { rir o homem honesto. (CAMUS, 1989, } \\
\text { p.20) } \\
\text { "compreendo então porque as doutrinas } \\
\text { que me explicam tudo, ao mesmo } \\
\text { tempo, me enfraquecem." (CAMUS, } \\
\text { 1989, p.42). }\end{array}$ \\
\hline 9. & $\begin{array}{l}\text { "baixeiosolhos, incurioso, lasso, } \\
\text { desdenhando colher a coisa } \\
\text { oferta". } \\
\text { "e o absurdo original e seus } \\
\text { enigmas,/ suas verdades altas } \\
\text { mais que tantos/ monumentos } \\
\text { erguidos à verdade". } \\
\text { (o "absurdo original" é um } \\
\text { despertar da percepção do } \\
\text { homem absurdo. Este despertar } \\
\text { é denominado por Camus como } \\
\text { "lassidão". É a lassidão que } \\
\text { acorda o homem ordinário de } \\
\text { sua vida maquinal, cotidiana, e o } \\
\text { conduz a uma preocupação com } \\
\text { a origem e com o destino de si } \\
\text { próprio e do mundo). }\end{array}$ & $\begin{array}{l}\text { "A lassidão está no final dos atos de uma } \\
\text { vida maquinal, mas inaugura ao mesmo } \\
\text { tempo o movimento da consciência." } \\
\text { (CAMUS, 1989, p.14). } \\
\text { "Aqui, eu tenho de concluir que ela [a } \\
\text { lassidão] é boa. Pois tudo começa com } \\
\text { a consciência e nada sem ela tem valor. } \\
\text { Essas observações não têm nada de } \\
\text { original. Mas são evidentes: por ora isso } \\
\text { é suficiente para a oportunidade de um } \\
\text { reconhecimento sumário das origens do } \\
\text { absurdo. A simples "preocupação" está } \\
\text { na origem de tudo." (CAMUS, 2019b, } \\
\text { p.I) }\end{array}$ \\
\hline
\end{tabular}




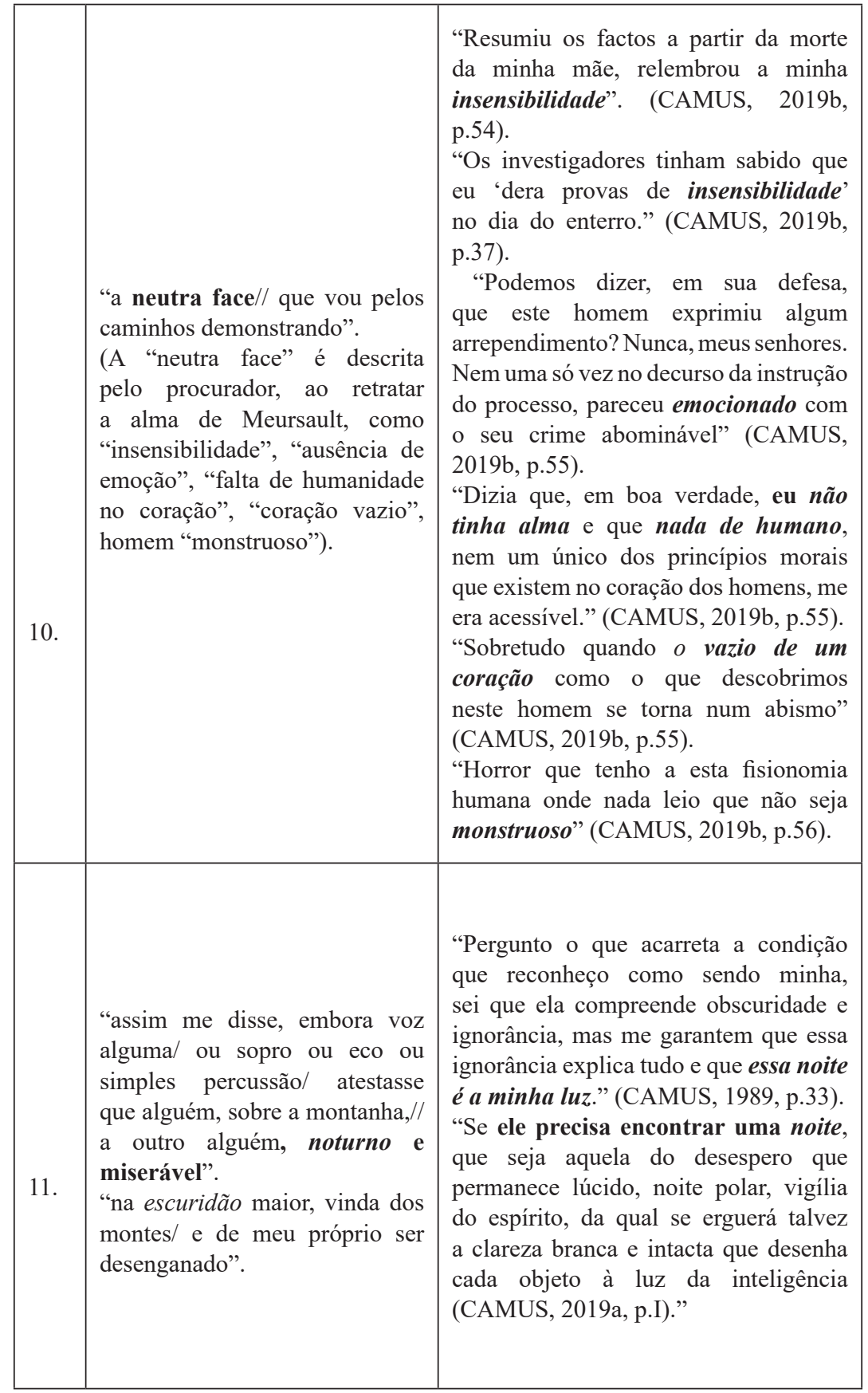

Fonte: Elaborada pelo autor. 
Dadas essas evidências, podemos concluir que o centro gravitacional do poema A Máquina do Mundo, ao que nos parece, não está nas obras de Dante ou Camões, mas no Livro de Sonetos de Jorge de Lima e n'O Mito de Sísifo de Albert Camus. Conscientemente, Drummond contrapôs a visão mecanicista da criação do mundo como obra da engenharia humana à visão mística da criação do universo como obra de Deus, ou seja, contrapôs a epifania profética de Jorge de Lima à epifania maquinal do mundo moderno. Essa contraposição entre duas epifanias filosoficamente antitéticas fora contemplada pelo poeta-narrador que, indiferente a ambas, decidiu por recusálas. Tal recusa se deu porque o poeta, segundo seu próprio testemunho, escolheu a via da indiferença, o caminho do homem absurdo e "suas verdades altas mais que todos/ monumentos erguidos à verdade [...]".

Drummond pensou o poema como uma narrativa que deveria descrever, "naquele relance", tanto a epifania maquinal do homem prometeico (explorador e dominador dos recursos da Terra) quanto a epifania teocêntrica do Livro de Sonetos de Jorge de Lima. Ante essas duas ofertas, o homem absurdo baixou os olhos, "incurioso, lasso", e decidiu seguir seu próprio caminho de recusa, "avaliando o que perdera". Na lógica da máquina do mundo, todos os deuses e religiões são invenções humanas, ou seja, Deus é criatura dos homens. Para Jorge de Lima, contrariamente, todas as criaturas são obras de Deus.

Dentre "os monumentos erguidos à verdade", certamente, estavam o Livro de Sonetos e A Divina Comédia, ambos, visões epifânicas poeticamente elaboradas da verdade cristã, considerada aí uma verdade não tão alta quanto as verdades do sentimento do absurdo ("e o absurdo original e seus enigmas,/ 
suas verdades altas mais que todos/ monumentos erguidos à verdade [...]"). A verdade cristã é una e singular ("à verdade"); as verdades do "absurdo original" são plurais ("verdades altas"), de modo que o poeta deixa aí implícito o dogma da unidade da fé cristã e o compara à convicção relativista da filosofia do absurdo e suas verdades subjetivas. Está claro, portanto, que tal vislumbre do "absurdo original e seus enigmas" revelou para Drummond as verdades mais elevadas dentre as verdades que ele pôde contemplar. Este terceto prenuncia, assim, a disposição espiritual absurdista do poeta que se pôs a recusar tanto as convicções do poderio humano de domínio do mundo quanto as convicções da fé cristã. Afinal, "o homem absurdo deve se esforçar por escapar ao universo de que é criador [...]" (CAMUS, 1989, p. 27).

\section{Referências}

ALMEIDA, C. R. R. "A máquina do mundo" em 3D: Drummond, leitor de W.H. Auden / "A máquina do mundo" in 3D: Drummond, reader of W.H. Auden. O Eixo e a Roda: Revista de Literatura Brasileira, [S.1.], v. 30, n. 2, p. 6-25, jun. 2021. ISSN 2358-9787. Disponível em: http://www.periodicos. letras.ufmg.br/index.php/o_eixo_ea_roda/article/view/17315. Acesso em: 08 dez. 2021.

ANDRADE, C. D. Poesia completa. Rio de Janeiro: Nova Aguilar, 2002.

ANDRADE, C. D. A Máquina do Mundo. Jornal Correio da Manhã, Rio de Janeiro, 2 de outubro de 1949. Disponível em: http://memoria.bn.br/DocReader/DocReader.aspx?bib=089842 _05\&pagfis $=49675$. Acesso em: 3 set. 2020. 
ANDRADE, C. D. A Máquina do Mundo. A Ordem, Rio de Janeiro, v. XLII, n.5, p. 44-48, novembro, 1949. Disponível em: http://memoria.bn.br/DocReader/docreader. aspx ?bib $=367729 \&$ pasta $=$ ano $\% 20192 \&$ pesq $=\&$ pagfis $=20780$. Acesso em: 3 set. 2020.

ARENDT, Hannah. A Condição Humana. 11. ed. Tradução de Roberto Raposo. Rio de Janeiro, Forense Universitária, 2011.

AUDEN, W.H. Collected Poems. Edited By Edward Mendelson. The Modern Library, New York, 2007.

BANDEIRA, Manuel. Poesia completa e prosa. 4. ed. Rio de Janeiro: Nova Aguilar, 1990.

BISCHOF, Betina. Razão da Recusa: Um Estudo da Poesia de Carlos Drummond de Andrade. São Paulo: Nankin, 2005.

BOSI, Alfredo. A máquina do mundo entre símbolo e alegoria. In: BOSI, A. Céu, inferno. São Paulo: Editora 34, 2003.

BRAGA, Rubem. Várias. Diário de Notícias. Rio de Janeiro, 28 de agosto de 1948. Disponível em: http://memoria.bn.br/ DocReader/DocReader.aspx?bib=093718_02\&Pesq=Camus\&p agfis $=47321$. Acesso em: 5 jun. 2021.

CAMÕES, Luís de. Os Lusíadas. Porto: Porto Editora, 1997.

CAMUS, Albert. Le Mythe de Sisyphe. Nouvelle edition augmentée d'une étude sur Franz Kafka. Paris: Les Éditions Gallimard. 69e édition, 2010. Disponível em: http://www. anthropomada.com/bibliotheque/CAMUS-Le-mythe-desisyphe.pdf. Acesso em: 3 set. 2020.

CAMUS, Albert. Albert Camus. Diário de Viagem. Rio de Janeiro: Record, 2017.

CAMUS, A. O Estrangeiro. Tradução de Valerie Rumjanek. Rio de Janeiro: Record, 2019a. [E-Book, paginação irregular] CAMUS, Albert. O Mito de Sísifo. Tradução de Ari Roitman e Paulina Watch. Editora Record, Rio de Janeiro, 2019b. [E-Book, 
paginação irregular]

CAMUS, Albert. O Mito de Sísifo. Tradução de Urbano Tavares Rodrigues. Livros do Brasil, Lisboa, 2020.

CAMUS, Albert. O Mito de Sísifo. Tradução de Mauro Gama. Rio de Janeiro, Editora Guanabara, 1989. Disponível em: http://bibliotecadigital.puc-campinas.edu.br/services/e-books/ Albert\%20Camus-2.pdf. Acesso em: 3 set. 2020.

CAMUS, A. L'étranger. Paris: Gallimard, 1942.

DALL'ALBA, Eduardo. Drummond, leitor de Dante. Universidade de Caxias do Sul, 1996.

DE CASTRO CÂNDIDO, Sara; RIBEIRO DA COSTA, Návia Regina; NOGUEIRA, Ruzileide Epifânio. O Homem Absurdo na Filosofia Camusiana e na Poesia Drummondiana: A Linguagem como Fonte da (Trans)formação. Revista Fragmentos. Goiânia, v. 27, n. 3, p. 361-375, nov. 2017.

DIAS, Maurício S. A máquina melancólica. Folha de São Paulo. São Paulo, 02 de janeiro de 2000. Caderno Mais. Disponível em: https://www1.folha.uol.com.br/fsp/mais/fs0201200017.htm. Acesso em 5 jun. 2021.

FAITININ, Paulo. Pessoa: a essência e a máscara, Aquinate, $n$. 3, 2006.

GESKE, S. F. A. O. de L. e S. Dos desencontros ao encontro: a viagem de Albert Camus ao Brasil em 1949. Revista Criação \& Crítica, n. 28, p. 20-49, 2020. Disponível em: https://doi. org/10.11606/issn.1984-1124.i28p20-49. Acesso em: 3 dez. 2021.

HETERONOMIA. In: HOUAISS, Antônio. Dicionário eletrônico Houaiss da língua portuguesa. Ed. Objetiva, 2009. LIMA, Jorge de. Obra Completa. Rio de Janeiro: Nova Aguilar, 1997.

PERIUS, Cristiano. Drummond e o humanismo. Scripta, v. 19, 
n. 37, p. 219-234, 2015. Disponível em: https://doi.org/10.5752/ P.2358-3428.2015v19n37p219. Acesso em: 02 jun. 2020.

PRADO JR, Bento. Sartre nos trópicos. [Entrevista cedida a] Cauê Alves. Revista Trópico, São Paulo, 7 jan. 2014. Disponível em: http://ogostodoquando.blogspot.com/2014/01/ sartre-e-drummond-por-bento-prado-junior.html. Acesso em: 02 jun. 2020.

SANTIAGO, Silviano. Camões e Drummond: A Máquina Do Mundo. Hispania, v. 49, n. 3, p. 389-394, 1966. Disponível em: www.jstor.org/stable/337450. Acesso em: 5 jun. 2021.

SILVA, Vítor Aguiar. Dicionário de Luís de Camões (2011). São Paulo: Leya, 2011.

SOCIAIS. Correio da Manhã (RJ), Rio de Janeiro, 02 de agosto de 1949. Recepções. Disponível em: http://memoria.bn.br/ DocReader/docreader.aspx?bib $=089842 \_05 \&$ pasta $=$ ano $\% 20$ $194 \&$ pes q $=$ C a r 1 os $\% 20$ D r u m m ond \% 20 de $\% 20$ Andrade\&pagfis $=48596$. Acesso em: 5 jun. 2021.

TAKAO, Andressa Santos. A náusea existencialista de Drummond e de Sartre: A rosa do povo e A Náusea. 2018. $91 \mathrm{f}$. Dissertação (Mestrado em Letras) - Universidade Federal do Espírito Santo, Vitória, 2018. Disponível em: http://repositorio. ufes.br/handle/10/9218 Acesso em: 5 de jun. 2021. 